\title{
French neo-colonial influence on Moroccan language education policy: a study of current status of standard Arabic in science disciplines
}

\author{
Marouane Zakhir ${ }^{1}$ (D) Jason L. O'Brien ${ }^{2}$
}

Received: 12 April 2015/Accepted: 14 December 2015/Published online: 2 February 2016

(C) The Author(s) 2016. This article is published with open access at Springerlink.com

\begin{abstract}
This paper reports the findings of a study on the attitudes of teachers and students regarding the language policy of the Moroccan educational system. Its primary goal is to explain the gap existing between the policy of Arabisation (i.e., the official adoption and utilization of Standard Arabic) and its practical implementation in science classrooms. Conducted in seven public and private high schools in two major cities in Morocco, the study examines the attitudes of students and teachers towards their level of competence in Standard Arabic, the validity of Standard Arabic as a medium of science instruction, and the future status of Arabisation in science disciplines, in particular, and in education, in general. This attitudinal study can be used to describe the status of Arabisation in the Moroccan education system and to elucidate some of the obstacles impeding its implementation.
\end{abstract}

Keywords Language policy · Arabisation - Standard Arabic $\cdot$ French $\cdot$ Science education · Neocolonialism

\section{Introduction}

The withdrawal of French colonizers in 1956 left Moroccans with a difficult choice: utilize French as a medium of instruction to modernize education and society, or choose Standard Arabic to restore Arab and Islamic values. In the case of Morocco, the colonial influence of the French was difficult to mediate; despite the adoption of the Arabisation project, few classroom teachers embraced Arabic as the language of

Marouane Zakhir

prof.zakhir@gmail.com

1 Faculty of Sciences of Education, Mohammed V University in Rabat, Rabat, Morocco

2 University of Alabama in Huntsville, 301 Sparkman Drive, Huntsville, AL, USA 
instruction. The unwillingness to fully implement Standard Arabic (SA) for instructional purposes paved the way for French to flourish in schools, especially in science classrooms, which by their very nature contain complex vocabulary. This study examines the status of Standard Arabic in science classes in light of current changes in national Moroccan language policies such as the launching of the National Charter for Education and the Emergency Plan, and the adoption of a new Constitution (2011) that recognizes Amazigh together with Standard Arabic as two official languages. It attempts to explain the effects of the attitudes of science students and teachers towards Standard Arabic on its spread in education. Based on existing research (Hammoud 1982; Bentahila 1983; Gharib 1996; Saidi 2001; Fassi Fihri 2003; and Marley 2004), this study was conducted under the assumption that there is a strong relationship between the negative attitudes of teachers and students towards Standard Arabic in science disciplines and the failed implementation of the Arabisation project in education. To examine this issue, the present empirical research uses quantitative and qualitative methods to uncover shareholders' attitudes towards language use in science classrooms.

\section{Arabisation in education}

Before French colonization, Morocco had a traditional education system based on Islam. Students would study in Quranic primary schools (msid) and Quranic secondary schools (madrasa). At the center of these schools' curriculum was memorization of the Quran, as well as learning basic literacy (Ennaji 2005). Those who scored sufficiently high on examinations could either follow their higher education in the 'Qaraouin' university or in France. Classical Arabic was the dominant language of instruction of religion, literature, history and sciences. From 1912 to 1956, Morocco was governed as a French protectorate, and as such, French gained elevated status in the country (Zouhir 2013). To encourage its use, colonizers built many schools in which the sole language of instruction was French. They built French schools for children of the French community and Moroccan elites, thus privileging those fluent in its use. To resist French hegemony, Moroccan nationalists established private schools (called al madaris alhurra), in which Arabic was the main language of instruction. However, these schools served a relatively small number of students and thus had little effect on the widespread use of French in the education system (Bentahila 1983).

With Moroccan independence in 1956, the Moroccan education system underwent several changes. Most notably, the government launched the project of Arabisation to revive Standard Arabic and to unify the education system and the Moroccan people. Mohammed El Fassi, the first Minister of Education in independent Morocco, attempted to Arabise 'le cours préparatoire' (the preparatory course) in 1957, but he faced much criticism, and he subsequently resigned. Much of this criticism came from Amizagh leaders who felt threatened by Arab nationalism and saw the Arabisation project as an attempt to diminish the use of their language in Morocco (Marley 2004). Later in 1958, a 'Commission Royale de l'Enseignement' was held to discuss the main impediments to Arabisation. To 
compensate for the shortage of Moroccan teachers proficient in the use of Standard Arabic, this Commission decided to hire Arabic teachers from Egypt and the Middle East. Hence, a number of teachers arrived from Egypt and Syria in 1958 (Grandguillaume 1983).

Another important event which affected Arabisation was the organization of the first 'Congrès de l'Arabisation' which led to the establishment of the 'Bureau Permanent du Congrès' in Rabat in 1960 and, later, the 'Institut d'Etudes et de Recherches pour l'Arabisation.' While these organizations had the shared goal of full implementation of Arabic, they faced many challenges. Notable obstacles were the shortage of materials written in Arabic, the shortage of qualified teachers, and the decrease of students' achievement in sciences. Accordingly, in 1965 the Minister of National Education decided to stop the project of Arabisation and to restore the French system of education instead (Ennaji 2002). This event was a major setback to the Arabisation project and it required many years to revive it by the minister in 1970. The latter refused to allow the use of French in teaching exact sciences in the secondary school system and instead gave priority to Standard Arabic. This has led to what Boukous (2009) characterizes as a "power struggle" in which Moroccan Arabic and Standard Arabic represent weak social and symbolic capital (p. 128). French was kept as the primary language of science instruction at Moroccan universities.

The year 2000 brought significant changes to Moroccan language policy. The Ministry of National Education launched the National Charter for Education, which aimed, among other things, to reform the status of languages in education. It provided a set of mandates to improve the use of Standard Arabic in Moroccan schools. However, the Charter was condemned by critics as nebulous and lacking clearly-defined objectives. Moroccan scholars, for instance, stated that the eradication of the term Arabisation from the Charter reflected the awareness of authorities of the negative connotations it held among students and teachers (Berdouzi 2000). Observers have noted that this lack of clarity of the goals of the Charter has had a negative effect on the status of Standard Arabic in education, particularly in science disciplines.

In 2008, the Ministry of National Education launched the Emergency Plan for the period 2009-2012 to increase the effectiveness of the Charter. Enacted using a $\$ 60$ million grant from the World Bank's Board of Directors, this plan urged teachers to use new materials and approaches in teaching Standard Arabic and encouraged its use as a medium of science instruction (World Bank 2010). Nevertheless, the goals of this plan to advance Arabisation in education were impeded by the widespread use of French as a medium of science instruction at university, the problematic practices of teachers in classrooms, and the negative attitudes of students towards Standard Arabic.

\section{Research methodology}

Based on the hypothesis that negative attitudes of both students and teachers towards Standard Arabic in science classes influence its use in education, the present research aims to examine the status of Standard Arabic through the attitudes 
of science students and teachers of science and Arabic at the secondary level. Due to the exploratory nature of this inquiry, a "sequential exploratory model," (Tashakkori and Teddlie 2003, p. 28) was used, in which quantitative survey data were analysed first and interview data were analysed last. It was hoped that the interview data would be used to both elucidate themes (e.g., negative connotations with Standard Arabic) found in previous research, as well as offer new insights into how teachers feel about the use of Standard Arabic as a medium of science instruction. The responses to the questionnaires are reported using descriptive statistics such as percentages and total number of occurrences. Interview data was transcribed and coded based on emerging themes reported by participants.

\section{Theoretical framework}

This study is based on the theoretical framework known as "Social Constructivism." Within the realm of social science research, the term constructivism refers to the belief that people construct their own understanding of reality. Some theorists go so far as to argue that there is no objective reality outside people's constructs or perceptions (Oxford 1997). Social Constructivism (Cobb 1994; Phillips 1995) focuses on the social nature of the learning process and in this case, represents the "construction" of reality by both teachers and students in Morocco. An important assumption of the authors of this paper is that the participants interact with and make important decisions (whether consciously or not) regarding their use of Standard Arabic, Moroccan Arabic or French. As such, asking students and teachers questions and then conducting interviews seem an appropriate methodological choice to describe and then analyze the choices stakeholders make regarding language. Furthermore, for the purposes of this study, the term "attitude" will be defined as "feelings, thoughts, or actions toward a phenomenon" (in this case language use by both students and teachers) in Moroccan schools (Sapsford 1999).

\section{Participants}

In this study, 199 respondents were utilized. One hundred and thirty-six students were randomly chosen from Life and Earth Sciences (henceforth LES) courses in the second year Baccalaureate level. Students in Morocco spend 3 years in their secondary studies at the high school level. The first year consists of a set of common (core) courses and then students proceed to complete first and second year baccalaureate courses. Students were purposefully chosen from second year baccalaureate classes because they had all studied Standard Arabic for 12 years both as a discrete subject and as a language of science instruction and second year baccalaureate students graduate to university the following year.

Ninety-six students attended three public schools and forty were randomly chosen from two private schools in two major cities in Morocco. Sixty-two students were male while seventy-four were females. Their ages ranged from 16 to 21 . Twenty one identified as Amazigh while one hundred and fifteen identified 
themselves as Arabs. The choice of science disciplines as an environment of the study was not random, for previous researchers (Gharib 1996; Fassi Fihri 2003, 2013) have shown that science students achieve lower results in Standard Arabic than their counterparts from other academic disciplines. An additional rationale is that science students are more concerned with the issue of Arabisation than the other students due to the linguistic shift from Standard Arabic to French when they matriculate from secondary school to the university.

The researchers collected responses from 63 teachers. Thirty-three were chosen from public schools and thirty were selected from private schools. Of the 63 chosen, 27 were females and thirty-six were males. Across both groups, teachers' ages ranged from 26 to 60 . The participants' experience varied greatly. The majority of teachers $(\mathrm{n}=33)$ had taught between 11 and 20 years when data were collected; the next largest group $(n=21)$ had taught between 21 and 36 years, and a smaller number $(\mathrm{n}=9)$ had taught $5-10$ years. Teachers in this study came from two different ethnic backgrounds: 17 were Amazigh and 46 were Arabs. To gain a diverse cross sample, these teachers were chosen from various disciplines: 21 of them taught Standard Arabic and 42 taught Math, Physics/Chemistry, and Life and Earth Sciences. Fourteen teachers were chosen from each scientific discipline. Further, these teachers were selected from the same schools of the students who participated, and most of them had already taught these students in the common core or the first year Baccalaureate.

\section{Instruments}

The present research used questionnaires to measure the attitudes of the respondents towards Standard Arabic and Arabisation in science disciplines. In the following paragraphs, the three different questionnaires are explained in detail. Types of questions on all three instruments included yes/no questions, open-ended questions and questions which required participants to rate their level of agreement using Likert scales. Questionnaires and agreement scale tests have routinely been utilised over the past several decades in psycho-sociolinguistic studies and yielded valid and reliable results (Bentahila and Davies 1983; Saidi 2001).

\section{Science students' questionnaire}

The science students' questionnaire was divided into three main parts: the first part consisted of questions regarding demographic data (e.g., sex, age, region and home language); the second part examined students' attitudes towards their competence and interest in Standard Arabic; and the third part asked about their views on Arabisation in science disciplines.

\section{Science teachers' questionnaire}

The science teachers' questionnaire was divided into four main parts: the first part gathered biographical information such as sex, age, region, and educational 
experience; the second part dealt with teachers' competence in Standard Arabic; the third part examined teachers' attitudes towards Arabisation and the use of Standard Arabic as a medium of science instruction; and the fourth component examined teachers' views on the future status of Standard Arabic in education.

\section{Arabic teachers' questionnaire}

The questionnaire addressed to teachers of Arabic involved four parts: the first part contained questions pertaining to demographic information; the second examined teachers' views on Arabisation in education; the third asked teachers to share their attitudes towards students' competence and interest in Standard Arabic; and the fourth examined teacher attitudes towards the future status of Standard Arabic in education.

\section{Data presentation}

\section{Science students' attitudes}

The following section presents the results of the questionnaire administered to science students. These results are grouped into three main categories: students' self-assessment of their competence in Standard Arabic, their attitudes towards Arabisation in science disciplines and towards Standard Arabic use and acquisition. Harkening back to the social constructivist paradigm, the authors believe that students' beliefs about their competence in speaking Standard Arabic would have a significant impact on their views regarding its use in classrooms. Likewise, querying the students about the use of Standard Arabic in science classrooms would provide valuable insight into either overall positive or negative viewpoints on its use as a medium of instruction and of learning. The following are the individual questions and responses gathered using survey instrumentation.

\section{Science students' attitudes: discussion}

Appendix 1 contains response rates for specific questions asked of students who participated in this study. Regarding science students' attitudes towards their proficiency in Standard Arabic, in both public and private school student groups, barely more than one in four students (27 and $28 \%$, respectively) rate their proficiency as 'very good' or 'good.' Furthermore, as close to $70 \%$ of students in both groups were 'unsatisfied' with their SA proficiency, these results indicate that formal attempts to teach students Standard Arabic have been less than effective. Written comments were replete with references to university policies which interfere with students' motivation to learn SA. Respondent 3 (private school) stated "My level of SA is average and I am satisfied with it. I don't need it after Baccalaureate, so why should I bother myself with learning it?" Respondent 5 (private school) mentioned "I am not satisfied with my level of SA, but it is okay because I will study in French at university." While these students sense their lack 
of efficacy in the use of SA, they seem unconcerned because they understand that their future success in learning science at university is solely dependent on their proficiency in French. Respondent 10 (private school) summed up the attitudes of many of his colleagues when he stated "It's not a question of satisfied or unsatisfied. It is a question of what SA mastery can give me in the future. French is the dominant language in science at the university, so that is where I will place my efforts."

When asked about the nature of SA, many students wrote responses that indicated a proclivity to view SA as a language of religion and identity. The fact that so few participants (14.5 and $10 \%$, respectively) associated Arabic with "progress and modernity" indicates that many of the students do not see Arabic as a language of science. Undoubtedly, this attitude has to do with the fact that students encounter Arabic while attending prayer sessions in mosques and while using it for a variety of purposes in everyday life. Respondent 17 (public school) stated, "Standard Arabic is the vehicle of our Islamic culture and identity; it is the language through which we pray and read the Qur'an." These comments mirror findings by Bentahila (1983), who demonstrated in his research regarding bilingualism that Arabic receives higher ratings in religious topics among Moroccan bilinguals. He posited that these attitudes exist due to "the close association between Arabic and Islam" (p. 21).

Several students wrote comments which indicated that they felt that SA is actually incompatible with science. Respondent 3 (public school) wrote "I need SA to do my prayers and also to read Arabic literature but when it comes to sciences I prefer French. French is modern and practical." Respondent 6 (public school) stated "SA has a bad connotation in science. Its classical system signifies what is old and static. Though I use it in my religion, I don't want it to be a language of sciences. I prefer French because it is modern and prestigious." Several students made comments concerning the dearth of scientific research written in Arabic as an impediment to them wanting to study it. Respondent 10 (public school) said, "Yes, SA is part of our identity. God speaks SA in the Qu'ran, but I can't imagine it as a medium of science progress. The Arab world is weak in scientific research." Another participant (12; public school) wrote "French is a modern, practical language. If we apply SA at university, we will have problems of research in the sciences."

Next students were asked to explain their attitudes towards the Aribisation Project as it pertained to their educational experiences. An interesting difference emerged from the responses. A much higher number of private school students $(47.5 \%)$ than public school students $(28.12 \%)$ reported having negative attitudes towards the Arabisation project as it pertained to science instruction. A vast majority of both groups, however, felt that only a partial implementation of the Arabisation was preferable to a full implementation. One of the private school students, (Respondent 22) stated, "The current Arabisation project is not consistent; it enhances our problems in studying sciences, particularly when we reach university where French is the sole medium of instruction." Echoing a preference for partial Arabisation, Respondent 73 (public school) added, "Complete Arabisation relies not only on the translation of Western sciences, but also on the local development of scientific research, which is not easy for a developing country like Morocco, where the rate of illiteracy is still high and the financial resources devoted 
to education and research are weak. Therefore, partial Arabisation is still the best solution at least at the present time."

Conversely, one of the public school students, (Respondent 11) claimed, "Arabising sciences can be both positive and negative; it is positive in the sense that it helps us to learn sciences in a language which we all know and master, and it is negative in the sense that its role ends immediately after gaining the high school diploma." Other participants saw only negative outcomes associated with full implementation. Respondent 6 (private school) stated "I disagree with the complete Arabisation of the Moroccan educational system. The system is still weak, and French is the only way to keep us in touch with scientific discoveries in the rest of the world." Respondent 9 (public school) stated "There is a complete shortage of Arabic references in scientific libraries. Any attempt to Arabise the university may cause danger for our system of education." These responses indicate the importance that French plays both in instruction at the university and in published scientific research. Both of these factors seem to be important contributors to the resistance of embracing full Arabisation by science students.

When asked whether SA poses problems in the acquisition of science knowledge, clear majorities in both groups indicated a belief to the contrary. However, while the students did not see Standard Arabic as an impediment, clear majorities in both groups (public: $58.3 \%$; private $65 \%$ ) indicated a preference for French use at universities. Again, the written responses contained many references indicating a strong preference to study science in French for the same reasons stated previously. The most poignant response came from Respondent 5 (private school) when he wrote "SA in universities? This is funny. Of course French is better. It allows us to communicate our work in Europe." One student (respondent 10; public school) went so far as to indicate a belief that SA is held in low esteem by the global scientific community when he added "Who cares about SA in the world? It is not used in important scientific research. How can we write in a language nobody cares for in the world?"

Students were asked if SA acted as an impediment to their future success. The most common response from public school students indicated that they agreed $(41.6 \%)$ while the inverse was true from private school students $(55 \%$ believed that it did not impede their future success). A plausible explanation of these disparate results could be that students who attend private schools come from high socio-economic backgrounds and thus feel that they will be successful, regardless of their proficiency in Standard Arabic. Also of note, a consistent theme emerged from these responses in that French is seen by students as the preferred language in which to study science and that studying science in Standard Arabic is a less effective language in which to learn. Respondent 11(public school) stated, "The problem with Standard Arabic has nothing to do with its value or validity as a medium of instruction; rather, it has to do with the lack of its implementation at university."

Finally, students were asked to define the relationship between SA use and social status. Written comments recorded indicated that while four students indicated a sort of social promotion when using SA, many more students believe that using French elevates their status within society. Several students made comments about having better job prospects by mastering French, such as Respondent 8 (public 
school) who said, "SA leads to low-paying jobs. I prefer French because of the job opportunities," or Respondent 9 (private school) who stated "I want to be an engineer or a doctor. I don't think SA will help me realize my dreams. It has weak status in society." These written comments all indicate a strong inclination for students to associate French and not SA with science, modernity, and increased job prospects after graduating from university.

\section{Science teachers' attitudes}

The following section presents a study of the views of science teachers (Math, Physics/Chemistry and Life and Earth Sciences) on the status of Standard Arabic in science classes. Following the same themes as questions posed to students, the survey recorded attitudes of 42 respondents ( 22 in public schools and 20 in private schools) towards their levels of competence in Standard Arabic, Arabisation, the use of Standard Arabic as a medium of science instruction, and the future status of Standard Arabic in education.

\section{Science teachers' attitudes: discussion}

Appendix 2 contains response rates for specific questions asked of science teachers who completed the survey. A major assumption of the researchers is that for participants (whether they be students or teachers), their own perceived proficiency levels with Standard Arabic will significantly affect their attitudes towards its use. A contrast was evident in the responses from the two groups. All of the private school teachers felt that their competence was either very good or good when asked, while a smaller number $(72.7 \%)$ of the public school teachers shared this belief. Several teachers explained that their competence in Standard Arabic was lower because they had been educated solely in French during their high school and university classwork. Respondent 2 (public school) stated "I am instructed in French at university. This of course has a negative effect on my knowledge of SA." Four of the teachers mentioned that their proficiency in SA has gotten better, but only as adults and from a conscious effort through reading or practicing SA. Respondent 3 (private school) wrote "When I was appointed as a teacher I remember that I had many problems with SA, but now with 21 years of experience and practice I can say that I am good at it."

When asked about overall attitudes towards the Arabisation of science education, the highest percentages of responses $(63.6 \%$ public; $50 \%$ private) indicated a negative view of this process. During the interviews, teachers consistently complained about the problems Arabisation creates in science disciplines. Respondent 9 (private school), a teacher of Math, stated, "The project of Arabisation is useless; I am instructed in French and now I am teaching in Standard Arabic. This causes me too much trouble as I always resort to translation and code switching while explaining lessons." Another teacher (three; private school) wrote "Arabic is a dead language in science disciplines. I think it is our 
obligation to look for what is good for our children. French can best facilitate the task of learning science." This response references the problems students encounter who cannot cope with the change in the language policy at university and choose to finish their studies in faculties of Humanities instead. This attitude was also discovered by Ghareb (1996) in his study of Arabisation, as he documented that $40 \%$ of science students chose to continue their higher studies in faculties of Humanities due to their weaknesses in French.

Not all science teachers agreed, however. Three respondents shared views which reflected a rejection of French colonialism over language policy. One (teacher four; public school) stated "I do not want French to take the place of Arabic. Our children will lose their identity." And another (Respondent 1; public) was even more emphatic when he wrote "We should not eradicate SA from the system of education. It would be a shame. Our ancestors worked hard to preserve this language. It is the language of the Qu'ran. Do you know that?" In summary, those teachers advocating SA's use in science seemed to invoke nationalist and patriotic sentiments, while those advocating for French seemed to be motivated by more pragmatic concerns (i.e., success at university).

A majority of teachers in both groups $(63.6 \%$ public; $75 \%$ private) also indicated that using scientific terminology created difficulties in instruction either often, or very often. When teachers were asked about the use of Standard Arabic language for instruction both groups overwhelmingly (roughly three out of four respondents, in both groups) did not feel that French should supplant Arabic in the teaching of scientific disciplines, nor did most teachers feel that scientific books should be published solely in French. Participant 8 (private school) warned "Even Arabic can be effective if we consciously work on it. A decision to supplant SA or its books by French will have dangerous effects on the system of education."

A majority of both public and private school teachers reported that using Standard Arabic caused difficulties in instruction. Respondent 3 (public school) commented, "The problem of terminology is one of the main deficiencies of this current project of Arabisation. Sometimes we find a French term with three or more Arabic equivalents." Respondent 6 (private school) echoed this concern when she stated "Sometimes I don't find the right equivalent for French terms. We still need to work on this issue of terminology; otherwise this project (Arabisation) will fail." These comments indicate that teachers feel that the use of Standard Arabic is appropriate for teaching science, but the major obstacle comes from the difficulties teachers face in translating between the two languages, which can be particularly vexing when textbooks and scientific publications are written in French.

The researchers asked teachers whether or not students' acquisition of science content was dependent upon their mastery of Standard Arabic. The results were opposite what we expected based on earlier responses. Most (77.2\% public; $100 \%$ private) teachers in both settings felt that mastering Standard Arabic was essential for students' success in the sciences. When we examined the comments of participants, we discovered that the question may have conflated the topics of 'success in science' and 'overall success in high school.' Respondent 2, a public 
school teacher of Life and Earth Sciences, stated, "High school students are obliged to master Standard Arabic so as to learn sciences. Without it they will not be successful." Respondent three (private school) wrote "Students who get poor results in SA are also poor students in sciences. How can they write in exams without a good mastery of SA?" Another echoed the belief that students who are deficient in SA will also earn poor marks in Science. He wrote (teacher six; private) "Students' acquisition of science depends on their competency in both SA and French. The student who doesn't know SA, his national language, will not master neither French nor sciences." This belief is logical in that all science subjects are taught in Standard Arabic at the level of secondary school, and a weak command of it may affect students' learning in science courses. Furthermore, students who are weak in SA may also not be strong students, thus leading to these beliefs by teachers.

The last section of the survey asked teachers to make a prediction about the future of SA in education. Overall attitudes indicated that most teachers in both groups feel that SA is in a state of decline. Respondent 2, a private school teacher of Life and Earth Sciences, pointed out, "The reason for Standard Arabic's decline is its failure to keep up with the development that sciences know." The same attitude was shared by another pubic school teacher (Respondent 7) who reported, "The stagnation of Standard Arabic and its lack of exploitation in scientific research will lead the Moroccan scientific community to give up using it in the future, hence its decline." Referencing again the impact of French use at university, Respondent 3 (public school) wrote "Of course SA is declining. We all know this. Students concentrate on the language they know will allow them to have success at university. This puts SA and the Project of Arabisation in serious jeopardy."

The above findings indicate that science teachers' attitudes towards Standard Arabic in science classes are ambivalent. They are torn between their views which see French as a powerful scientific language and Arabic as an underdeveloped language with a weak terminology, but also as the language of their identity. While teachers hold different views on the value and utility of Standard Arabic, almost all of them prefer French as a medium of science instruction. Also, the majority of teachers share pessimistic attitudes towards the future status of Standard Arabic, as they foresee it declining in the years to come. These negative attitudes towards Standard Arabic were not unexpected, based on the inconsistent nature in which the Arabisation project has been implemented through educational policy as well as its absence in scientific literature.

\section{Arabic teachers' attitudes}

Twenty-one teachers of Standard Arabic (eleven in public schools and ten in private schools) were asked to respond to a number of questions which examined their attitudes towards the status of SA. These questions focused on four main issues: teachers' attitudes towards students' competence and interest in SA, the effectiveness of the Arabisation project and the future status of SA in education. 


\section{Arabic teachers' attitudes: discussion}

Appendix 3 contains response rates for specific questions asked of teachers of Arabic who completed the survey. When both groups of teachers, private and public, were asked to rate their students' competence in Standard Arabic, none of the teachers answered 'very good.' The main difference between the two groups' responses was that $27.2 \%$ of public school teachers rated the competence of their students as either 'weak' or 'very weak' while none of the private school teachers indicated the same. Recognizing that other researchers (Oxford et al. 2008) have recognized strong connections between motivation and language learning, teachers were asked to describe their students' interest levels in learning Standard Arabic. Here, an important difference emerged between the attitudes of public and private school teachers of Arabic. Specifically, all of the private school teachers indicated their beliefs that their students were 'uninterested' in learning Standard Arabic. A possible explanation was offered by Participant 5 (Private school teacher), who stated, "The fact that Standard Arabic subject is excluded from the final exam of the second year of the Baccalaureate level makes students unconcerned to learn it." Another teacher (Participant 7, private school) stated, "My students' lack of interest is due to their awareness that they will pursue their university studies in French."

Arabic teachers reported contradictory attitudes when asked about both the implementation and effects of the Arabisation project. A clear majority of Arabic teachers (72.7 \% public; $90 \%$ private) support implementing 'complete Arabisation' with students. Respondent 7 (public school) invoked nationalism when he said, "Complete Arabisation is the solution. We are Arabs and we should be proud of our language. If we train teachers of science to teach SA, our students will love it and work on its advancement." Another teacher (Respondent 2; private school) said "Arabisation is good since it helps student learn in their own language, Arabic, but it is implemented wrong. It should cover all levels of education."

However, at the same time, roughly $80 \%$ of the teachers in both groups indicated a belief that Standard Arabic actually impedes students' integration into the job market. It is not difficult to see why teachers of SA would advocate its full implementation, however it is difficult to reconcile their beliefs if complete implementation would actually be detrimental to their students' future job prospects. Every one of the written comments pertaining to the effects of learning SA and employment mentioned a negative effect associated with SA. Respondent 4 wrote "(SA) is a handicap for students. Companies use French, not SA." Respondent 6 (public school) mentioned "SA is needed only in education and low-paid jobs. It is not used in economy because Morocco has many relations with France."

The last theme explored was Arabic teachers' predictions regarding the future of SA in education. Predictably, a clear majority (63.6\% public; $100 \%$ private) of teachers indicated a belief in its decline. Respondent 4 (private school) stated "SA is declining. Unless there is a real effort to foster it in all levels of education, we will sooner or later see its death." Respondent 6 (private school) again mentioned the role of universities in the decline of SA. He wrote "Students' levels in SA are declining day by day. This is the outcome of dominance of French and the 
reluctance of the government to improve translation and foster Arabisation in all levels of education, especially universities." The two teachers who did not feel that SA was in decline both felt that Moroccans would never allow French to supplant SA because of their strong sense of an Arab identity.

\section{Implications of results}

It is clear that the Arabisation project has faced many obstacles in its implementation in Moroccan society. The attempt by proponents of the Arabisation project to 'unite the country' using Standard Arabic did not fully take into account the multilingual nature of Morocco (Agnaou 2004). Amizagh, Standard Arabic, Moroccan Arabic, and French are all used by Moroccan citizens for official and informal uses. Both students and teachers are expected to learn Standard Arabic through primary and secondary schools, yet they face the reality that when they arrive at university, the French language is given priority. Bullock (2014) explains that French is still the dominant language of instruction in the faculties of medicine, engineering, science, technology, business and management.

Except for faculties of Humanities and Islamic studies, universities rely primarily on French because academic references and textbooks are written in French, there is a shortage of Moroccan professors with mastery of Standard Arabic, and the socioeconomic environment makes French popular because most of Morocco's international trade partnerships are with France (p. 39). Pennycook (2001) wrote "pedagogic choices about curriculum development, content, materials, classroom processes, and language use....are inherently ideological in nature with significant implications for learners' socioeconomic roles" (p. 115). These pedagogic choices about language use in science classrooms seem to have a major impact on teachers' and students' attitudes.

Attitudes of teachers and students in this study indicate a realization of French's elevated status at university as an impediment to embrace its full acceptance in secondary schools. A majority $(61.3 \%)$ of public school students interviewed saw Standard Arabic as an impetus to future success while clear majorities of science teachers (95.4\% public; $100 \%$ private) predict that Standard Arabic's use will decline in the future. Coupled with the finding that $80 \%$ of teachers surveyed see the use of Standard Arabic as impeding students' integration in the job market, Standard Arabic as a medium of instruction seems likely to face consistent resistance until these attitudes change. Possibly the most troubling finding for those who support the Arabisation project is that a majority $(63.6 \%$ public; $100 \%$ private) of Arabic teachers themselves see the language as in a period of decline.

The authors of this paper expected to find overall negative attitudes towards Standard Arabic's use in science classes, in particular, and education, in general. However participants' attitudes across all three groups (students, math/science teachers, and teachers of Arabic) demonstrated that Standard Arabic is still seen as an important part of Moroccan culture, especially as it is used in religion and in studying literature. Some of the students indicated a sense of social promotion when using Standard Arabic, and most of the teachers surveyed disagreed that French should supplant Arabic in the scientific disciplines. These findings mirror Zouhir's 
work (2013) which found that "Standard Arabic competes for prestige with French in several social and professional fields" (p. 274). Harm de Blij (2009) describes language as the "epoxy of culture" and states that "people often feel passionately about their mother tongue, especially when it is threatened by the language of a colonizer" (p. 31). Unfortunately for the Arabisation project, Moroccan universities themselves are complicit in giving elevated status to the language of the colonizer, thus impeding its acceptance. Even if a majority of Moroccans were to support abandoning Standard Arabic in the study of science, there is little doubt that many would still feel a strong sense of connection to the language they use for religion and for communication. The success or failure of future attempts to enact the Arabisation project will undoubtedly hinge on proponents' ability to navigate the tension created between the two languages. To help further explain this tension between French and Standard Arabic, we turn to the effects of colonialism in current Moroccan society.

Although Morocco became independent in 1956, the influence of French colonization is still keenly felt. Scholars mention the impacts of neo-colonialism, which is the geopolitical practice of using capitalism, business globalization, and cultural imperialism to influence a country, in lieu of either direct military control or indirect political control (Azikiwe 2014). By teaching science in French, universities are implementing policies detrimental to the Arabisation project and which only solidify French's status within Morocco. Compounding this is the dearth of scientific articles published in Standard Arabic, a problem that is not easily remedied. Recognizing that the vestiges of colonialism still play an important part of the cultural fabric of life and of education, perhaps officials in the Ministry of Education should accept the fact that Morocco is a multilingual society and accept the important role that French plays in both educational and business spheres.

In his paper on language conflict in Morocco, Zouhir (2013) states his belief that the future of language policy in Morocco will be significantly impacted by English. His rationale is that the process of globalization has promoted American beliefs, values, media, and practices in Morocco. He also argues that Moroccans are more likely to accept English because it is not associated with colonization, as French and Spanish are. While it is impossible to know what the future holds regarding the status of languages in Morocco, what is clear is that the Arabisation project has failed at privileging Standard Arabic as a language of instruction in the sciences.

\section{Future directions for research}

Students and teachers in this study, report attitudes that are significantly influenced by university professors' practice of teaching science courses in French at Moroccan universities. Future researchers might consider asking professors of these courses what they perceive as specific impediments that keep them from teaching science courses in Arabic. Also, since a majority of participants in all three groups felt like Standard Arabic is a language in decline, it seems important to uncover why they feel this way. It is unlikely that complete Arabisation will be effective if students and teachers do not have a positive outlook on the future of Standard Arabic's role in both society and the sciences. Finally, this study was conducted in the middle and 
north-west of Morocco. It would be of interest to researchers to see if students and teachers in the southern portion of the country share these same views as to the status of both French and Standard Arabic as it pertains to their educational experiences.

\section{Conclusion}

The findings of this paper highlight the linguistic tensions which exist between Standard Arabic and French as they compete with one another in education settings. Morocco has always been a multilingual country with Standard Arabic, Moroccan Arabic, Amizagh, and French (and to a lesser extent, Spanish) being used in variety of settings and for a multitude of purposes. It is clear that to Moroccans, language represents more than simple communication. Language concentrates symbolic capital, through its use, and grants privilege and access to cultural, economic, and educational resources. It seems clear that any future attempts at successful implementation of the Arabisation project will be met with resistance from teachers and students as long as French is the preferred language of instruction at universities. Policy makers should consider that if the goals of the Arabisation project are ever to be fully realized, it will require buy in from both students and teachers. Attitudes uncovered in this empirical research indicate that at the present time, this buy in is not apparent in students or in teachers of the sciences due to the influence of French.

Open Access This article is distributed under the terms of the Creative Commons Attribution 4.0 International License (http://creativecommons.org/licenses/by/4.0/), which permits unrestricted use, distribution, and reproduction in any medium, provided you give appropriate credit to the original author(s) and the source, provide a link to the Creative Commons license, and indicate if changes were made.

\section{Appendix 1: Science student responses}

Question 1: Please rate your proficiency level in Standard Arabic

\begin{tabular}{llllll}
\hline Students & Very good & Good & Average & Weak & Very weak \\
\hline $\begin{array}{c}\text { Public } \\
\text { schools }\end{array}$ & $0 \%(\mathrm{n}=0)$ & $28.12 \%(\mathrm{n}=27)$ & $48.95 \%(\mathrm{n}=47)$ & $22.91 \%(\mathrm{n}=22)$ & $0 \%(\mathrm{n}=0)$ \\
$\begin{array}{c}\text { Private } \\
\text { schools }\end{array}$ & $10 \%(\mathrm{n}=4)$ & $17.50 \%(\mathrm{n}=7)$ & $45 \%(\mathrm{n}=18)$ & $27.5 \%(\mathrm{n}=11)$ & $0 \%(\mathrm{n}=0)$ \\
\hline
\end{tabular}

Question 2: Are you satisfied with your level of competence in Standard Arabic?

\begin{tabular}{llll}
\hline Students & Satisfied & Unsatisfied & Blank \\
\hline Public schools & $25 \%(\mathrm{n}=24)$ & $69.79 \%(\mathrm{n}=67)$ & $5.20 \%(\mathrm{n}=5)$ \\
Private schools & $20 \%(\mathrm{n}=8)$ & $72.50 \%(\mathrm{n}=29)$ & $7.50 \%(\mathrm{n}=3)$ \\
\hline
\end{tabular}


Question 3: What does Standard Arabic represent for you?

\begin{tabular}{lllll}
\hline Students & $\begin{array}{l}\text { Language of religion } \\
\text { and identity }\end{array}$ & $\begin{array}{l}\text { Language of the past } \\
\text { and decline }\end{array}$ & $\begin{array}{l}\text { Language of progress } \\
\text { and modernity }\end{array}$ & Blank \\
\hline $\begin{array}{c}\text { Public } \\
\text { schools }\end{array}$ & $81.25 \%(\mathrm{n}=78)$ & $4.16 \%(\mathrm{n}=4)$ & $14.58 \%(\mathrm{n}=14)$ & $0 \%(\mathrm{n}=0)$ \\
$\begin{array}{c}\text { Private } \\
\text { schools }\end{array}$ & $80 \%(\mathrm{n}=32)$ & $7.5 \%(\mathrm{n}=3)$ & $10 \%(\mathrm{n}=4)$ & $2.5 \%(\mathrm{n}=1)$ \\
\hline
\end{tabular}

Question 4: Do you prefer Standard Arabic as a language of science, literature or both?

\begin{tabular}{|c|c|c|c|c|}
\hline Students & $\begin{array}{l}\text { Language of } \\
\text { literature }\end{array}$ & $\begin{array}{l}\text { Language of } \\
\text { science }\end{array}$ & Both & Blank \\
\hline Public schools & $61.45 \%(\mathrm{n}=61)$ & $9.37 \%(\mathrm{n}=9)$ & $23.95 \%(\mathrm{n}=23)$ & $3.12 \%(\mathrm{n}=3)$ \\
\hline Private schools & $80 \%(\mathrm{n}=32)$ & $7.5 \%(\mathrm{n}=3)$ & $12.5 \%(\mathrm{n}=5)$ & $0 \%(\mathrm{n}=0)$ \\
\hline
\end{tabular}

Question 5: How do you find the project of Arabising science disciplines?

\begin{tabular}{lllll}
\hline Students & Positive & Negative & $\begin{array}{l}\text { Has advantages and } \\
\text { disadvantages }\end{array}$ & Blank \\
\hline $\begin{array}{c}\text { Public } \\
\text { students }\end{array}$ & $23.95 \%(\mathrm{n}=23)$ & $28.12 \%(\mathrm{n}=27)$ & $47.91 \%(\mathrm{n}=46)$ & $0 \%(\mathrm{n}=0)$ \\
$\begin{array}{c}\text { Private } \\
\text { students }\end{array}$ & $12.50 \%(\mathrm{n}=5)$ & $47.50 \%(\mathrm{n}=19)$ & $40 \%(\mathrm{n}=16)$ & $0 \%(\mathrm{n}=0)$ \\
\hline
\end{tabular}

Question 6: Do you prefer partial or complete Arabisation project?

\begin{tabular}{llll}
\hline Students & Partial Arabisation & Complete Arabisation & Blank \\
\hline Public schools & $68.75 \%(\mathrm{n}=66)$ & $28.12 \%(\mathrm{n}=27)$ & $3.12 \%(\mathrm{n}=3)$ \\
Private schools & $75 \%(\mathrm{n}=30)$ & $17.5 \%(\mathrm{n}=7)$ & $7.5 \%(\mathrm{n}=3)$ \\
\hline
\end{tabular}

Question 7: Does Standard Arabic pose any problem in your learning of sciences?

\begin{tabular}{llll}
\hline Students & Yes & No & Blank \\
\hline Public schools & $17.70 \%(\mathrm{n}=17)$ & $82.29 \%(\mathrm{n}=79)$ & $0 \%(\mathrm{n}=0)$ \\
Private schools & $22.50 \%(\mathrm{n}=9)$ & $72.50 \%(\mathrm{n}=29)$ & $5 \%(\mathrm{n}=2)$ \\
\hline
\end{tabular}

Question 8: In what language do you prefer to study science at university?

\begin{tabular}{lllll}
\hline Students & SA & French & English & Blank \\
\hline Public schools & $30.20 \%(\mathrm{n}=29)$ & $58.33 \%(\mathrm{n}=56)$ & $9.37 \%(\mathrm{n}=9)$ & $2.08 \%(\mathrm{n}=2)$ \\
Private schools & $10 \%(\mathrm{n}=4)$ & $65 \%(\mathrm{n}=26)$ & $22.50 \%(\mathrm{n}=9)$ & $2.50 \%(\mathrm{n}=1)$ \\
\hline
\end{tabular}


Question 9: When I use Standard Arabic, I feel a sort of social promotion

\begin{tabular}{lllll}
\hline Students & I totally agree & I agree & I disagree & I totally disagree \\
\hline Public schools & $48.95 \%(\mathrm{n}=47)$ & $25 \%(\mathrm{n}=24)$ & $23.95 \%(\mathrm{n}=23)$ & $\begin{array}{l}2.08 \%(\mathrm{n}=2) \\
\text { Private schools }\end{array}$ \\
\hline
\end{tabular}

Question 10: If I weren't obliged to learn Standard Arabic, I wouldn't care about it

\begin{tabular}{lllll}
\hline Students & I totally agree & I agree & I disagree & I totally disagree \\
\hline Public schools & $0 \%(\mathrm{n}=0)$ & $21.87 \%(\mathrm{n}=21)$ & $45.83 \%(\mathrm{n}=44)$ & $\begin{array}{l}32.29 \%(\mathrm{n}=31) \\
7.5 \%(\mathrm{n}=3)\end{array}$ \\
Private schools & $37.5 \%(\mathrm{n}=15)$ & $25 \%(\mathrm{n}=10)$ & $30 \%(\mathrm{n}=12)$ & 7.5 \\
\hline
\end{tabular}

Question 11: I would learn sciences effectively if the language of instruction were not Standard Arabic

\begin{tabular}{lllll}
\hline Students & I totally agree & I agree & I disagree & I totally disagree \\
\hline Public schools & $27.08 \%(\mathrm{n}=26)$ & $33.33 \%(\mathrm{n}=32)$ & $17.70 \%(\mathrm{n}=17)$ & $21.87 \%(\mathrm{n}=21)$ \\
Private schools & $37.5 \%(\mathrm{n}=15)$ & $35 \%(\mathrm{n}=14)$ & $22.5 \%(\mathrm{n}=9)$ & $5 \%(\mathrm{n}=2)$ \\
\hline
\end{tabular}

Question 12: My ability to use Standard Arabic is an impetus for my future success

\begin{tabular}{lllll}
\hline Students & I totally agree & I agree & I disagree & I totally disagree \\
\hline Public schools & $41.66 \%(\mathrm{n}=40)$ & $19.79 \%(\mathrm{n}=19)$ & $21.87 \%(\mathrm{n}=21)$ & $16.66 \%(\mathrm{n}=16)$ \\
Private schools & $7.50 \%(\mathrm{n}=3)$ & $5 \%(\mathrm{n}=2)$ & $32.50 \%(\mathrm{n}=13)$ & $55 \%(\mathrm{n}=22)$ \\
\hline
\end{tabular}

\section{Appendix 2: Science teachers' responses}

Question 1: Rate your level of competence in Standard Arabic

\begin{tabular}{lcccccc}
\hline $\begin{array}{l}\text { Science } \\
\text { teachers }\end{array}$ & Very good & Good & Average & Weak & Very weak & Blank \\
\hline $\begin{array}{c}\text { Public } \\
\text { schools }\end{array}$ & $\begin{array}{c}27.27 \% \\
(\mathrm{n}=6)\end{array}$ & $\begin{array}{c}45.45 \% \\
(\mathrm{n}=10)\end{array}$ & $\begin{array}{c}9.09 \% \\
(\mathrm{n}=2)\end{array}$ & $\begin{array}{c}18.18 \% \\
(\mathrm{n}=4)\end{array}$ & $0 \%(\mathrm{n}=0)$ & $0 \%(\mathrm{n}=0)$ \\
$\begin{array}{c}\text { Private } \\
\text { schools }\end{array}$ & $\begin{array}{c}60 \% \\
(\mathrm{n}=12)\end{array}$ & $\begin{array}{c}40 \% \\
(\mathrm{n}=8)\end{array}$ & $\begin{array}{c}0 \% \\
(\mathrm{n}=0)\end{array}$ & $\begin{array}{c}0 \% \\
(\mathrm{n}=0)\end{array}$ & $0 \%(\mathrm{n}=0)$ & $0 \%(\mathrm{n}=0)$ \\
\hline
\end{tabular}

Question 2: How do you find the Arabisation of science education?

\begin{tabular}{lllll}
\hline Teachers & Positive & $\begin{array}{l}\text { It has advantages and } \\
\text { disadvantages }\end{array}$ & Negative & Blank \\
\hline Public schools & $27.27 \%(\mathrm{n}=6)$ & $9.09 \%(\mathrm{n}=2)$ & $63.63 \%(\mathrm{n}=14)$ & $0 \%(\mathrm{n}=0)$ \\
Private schools & $30 \%(\mathrm{n}=6)$ & $20 \%(\mathrm{n}=4)$ & $50 \%(\mathrm{n}=10)$ & $0 \%(\mathrm{n}=0)$ \\
\hline
\end{tabular}


Question 3: Do you prefer partial or complete Arabisation

\begin{tabular}{llll}
\hline Teachers & Partial Arabisation & Complete Arabisation & Blank \\
\hline $\begin{array}{l}\text { Public schools } \\
\text { Private schools }\end{array}$ & $27.27 \%(\mathrm{n}=6)$ & $54.54 \%(\mathrm{n}=12)$ & $18.18 \%(\mathrm{n}=4)$ \\
& $100 \%(\mathrm{n}=20)$ & $0 \%(\mathrm{n}=0)$ & $0 \%(\mathrm{n}=0)$
\end{tabular}

Question 4: Specify the difficulty you face in using Standard Arabic as a medium of teaching

\begin{tabular}{llll}
\hline Teachers & $\begin{array}{l}\text { Reading and } \\
\text { explaining }\end{array}$ & Writing & No difficulty at all \\
\hline Public schools & $27.27 \%(\mathrm{n}=6)$ & $18.18 \%(\mathrm{n}=4)$ & $54.54 \%(\mathrm{n}=12)$ \\
Private schools & $20 \%(\mathrm{n}=4)$ & $20 \%(\mathrm{n}=4)$ & $60 \%(\mathrm{n}=12)$ \\
\hline
\end{tabular}

Question 5: How often do you experience difficulties using scientific terminology in Standard Arabic?

\begin{tabular}{lcccccc}
\hline Teachers & Very often & Often & Sometimes & Rarely & Never & Blank \\
\hline $\begin{array}{c}\text { Public } \\
\text { schools }\end{array}$ & $\begin{array}{c}13.63 \% \\
(\mathrm{n}=3)\end{array}$ & $\begin{array}{c}50 \% \\
(\mathrm{n}=11)\end{array}$ & $\begin{array}{c}22.72 \% \\
(\mathrm{n}=5)\end{array}$ & $\begin{array}{c}4.54 \% \\
(\mathrm{n}=1)\end{array}$ & $\begin{array}{c}9.09 \% \\
(\mathrm{n}=2)\end{array}$ & $\begin{array}{c}0 \% \\
(\mathrm{n}=0)\end{array}$ \\
$\begin{array}{c}\text { Private } \\
\text { schools }\end{array}$ & $5 \%(\mathrm{n}=1)$ & $\begin{array}{c}70 \% \\
(\mathrm{n}=14)\end{array}$ & $10 \%(\mathrm{n}=2)$ & $\begin{array}{c}5 \%(\mathrm{n}=1) \\
10 \%\end{array}$ & $\begin{array}{c}0 \% \\
(\mathrm{n}=2)\end{array}$ & \begin{tabular}{c}
$(\mathrm{n}=0)$ \\
\hline
\end{tabular} \\
\hline
\end{tabular}

Question 6: I think that French should supplant Standard Arabic in scientific disciplines

\begin{tabular}{lllll}
\hline Teachers & I totally agree & I agree & I disagree & I totally disagree \\
\hline Public schools & $9.09 \%(\mathrm{n}=2)$ & $18.18 \%(\mathrm{n}=4)$ & $22.72 \%(\mathrm{n}=5)$ & $50 \%(\mathrm{n}=11)$ \\
Private schools & $0 \%(\mathrm{n}=0)$ & $25 \%(\mathrm{n}=5)$ & $0 \%(\mathrm{n}=0)$ & $75 \%(\mathrm{n}=15)$ \\
\hline
\end{tabular}

Question 7: I think scientific books should be published in French rather than in Standard Arabic

\begin{tabular}{lllll}
\hline Teachers & I totally agree & I agree & I disagree & I totally disagree \\
\hline Public schools & $9.09 \%(\mathrm{n}=2)$ & $22.72 \%(\mathrm{n}=5)$ & $27.27 \%(\mathrm{n}=6)$ & $40.90 \%(\mathrm{n}=9)$ \\
Private schools & $0 \%(\mathrm{n}=0)$ & $25 \%(\mathrm{n}=5)$ & $0 \%(\mathrm{n}=0)$ & $75 \%(\mathrm{n}=15)$ \\
\hline
\end{tabular}

Question 8: I think that students' acquisition of sciences depends on their mastery of Standard Arabic

\begin{tabular}{lllll}
\hline Teachers & I totally agree & I agree & I disagree & I totally disagree \\
\hline Public schools & $45.45 \%(\mathrm{n}=10)$ & $31.81 \%(\mathrm{n}=7)$ & $18.18 \%(\mathrm{n}=4)$ & $4.54 \%(\mathrm{n}=1)$ \\
Private schools & $85 \%(\mathrm{n}=17)$ & $15 \%(\mathrm{n}=3)$ & $0 \%(\mathrm{n}=0)$ & $0 \%(\mathrm{n}=0)$ \\
\hline
\end{tabular}

Question 9: What are your predictions about the future status of Standard Arabic in education?

\begin{tabular}{llll}
\hline Teachers & Developing & Declining & Blank \\
\hline Public schools & $31.81 \%(\mathrm{n}=7)$ & $63.63 \%(\mathrm{n}=14)$ & $4.54 \%(\mathrm{n}=1)$ \\
Private schools & $15 \%(\mathrm{n}=3)$ & $85 \%(\mathrm{n}=17)$ & $0 \%(\mathrm{n}=0)$ \\
\hline
\end{tabular}




\section{Appendix 3: Arabic teachers' responses}

Question 1: Rate your science students' level of competence in Standard Arabic

\begin{tabular}{llllll}
\hline $\begin{array}{l}\text { SA } \\
\text { teachers }\end{array}$ & Very good & Good & Average & Weak & Very weak \\
\hline $\begin{array}{c}\text { Public } \\
\text { schools }\end{array}$ & $0 \%(\mathrm{n}=0)$ & $18.18 \%(\mathrm{n}=2)$ & $54.54 \%(\mathrm{n}=6)$ & $18.18 \%(\mathrm{n}=2)$ & $9.09 \%(\mathrm{n}=1)$ \\
$\begin{array}{c}\text { Private } \\
\text { schools }\end{array}$ & $0 \%(\mathrm{n}=0)$ & $50 \%(\mathrm{n}=5)$ & $50 \%(\mathrm{n}=5)$ & $0 \%(\mathrm{n}=0)$ & $0 \%(\mathrm{n}=0)$ \\
\end{tabular}

Question 2: In your opinion, are students interested or uninterested in learning Standard Arabic?

\begin{tabular}{llll}
\hline SA teachers & Interested & Uninterested & Blank \\
\hline Public schools & $27.27 \%(\mathrm{n}=3)$ & $54.54 \%(\mathrm{n}=6)$ & $18.18 \%(\mathrm{n}=2)$ \\
Private schools & $0 \%$ & $100 \%(\mathrm{n}=10)$ & $0 \%$ \\
\hline
\end{tabular}

Question 3: Do you prefer partial or complete Arabisation?

\begin{tabular}{llll}
\hline SA teachers & Partial & Complete & Blank \\
\hline Public schools & $18.18 \%(\mathrm{n}=2)$ & $72.72 \%(\mathrm{n}=8)$ & $9.09 \%(\mathrm{n}=1)$ \\
Private schools & $0 \%(\mathrm{n}=0)$ & $90 \%(\mathrm{n}=9)$ & $10 \%(\mathrm{n}=1)$ \\
\hline
\end{tabular}

Question 4: Is Standard Arabic helpful or impeding for students' integration into the job market?

\begin{tabular}{llll}
\hline SA teachers & Helpful & Impeding & Blank \\
\hline Public schools & $18.18 \%(\mathrm{n}=2)$ & $81.81 \%(\mathrm{n}=9)$ & $0 \%(\mathrm{n}=0)$ \\
Private schools & $20 \%(\mathrm{n}=2)$ & $80 \%(\mathrm{n}=8)$ & $0 \%(\mathrm{n}=0)$ \\
\hline
\end{tabular}

Question 5: What is your prediction about the future status of Standard Arabic in education?

\begin{tabular}{llll}
\hline SA teachers & Developing & Declining & Blank \\
\hline Public schools & $27.27 \%(\mathrm{n}=3)$ & $63.63 \%(\mathrm{n}=7)$ & $9.09 \%(\mathrm{n}=1)$ \\
Private schools & $0 \%(\mathrm{n}=0)$ & $100 \%(\mathrm{n}=10)$ & $0 \%(\mathrm{n}=0)$ \\
\hline
\end{tabular}

\section{References}

Agnaou, F. (2004). Gender, literacy, and empowerment in Morocco. New York, NY: Routledge Publishing.

Azikiwe, A. (2014). Neo-colonialism and the changing nature of imperialism in Africa. Centre for Research on Globalization. Available at http://www.globalresearch.ca/neo-colonialism-and-thechanging-nature-imperialism-in-africa/5385713.

Bentahila, A. (1983). Language attitudes among Arabic-French bilinguals. Clevedon: Multilingual Matters.

Bentahila, A., \& Davies, E. (1983). The syntax of Arabic-French code-switching. Lingua, 59(4), 301-330.

Berdouzi, M. (2000). Rénover l'enseignement: de la charte aux actes. Rabat: Renouveau. 
Boukous, A. (2009). Globalization and sociolinguistic stratification in North Africa: The case of Morocco. In C. B. Vigourous \& S. Mufwene (Eds.), Globalization and language vitality: Perspectives from Africa (pp. 127-141). London: Continuum International.

Bullock, S. (2014). Language ideologies in Morocco. Anthropology Department Honors Papers. Paper 11. http://digitalcommons.conncoll.edu/cgi/viewcontent.cgi?article $=1007 \&$ context $=$ anthrohp.

Cobb, P. (1994). Where is the mind? Constructivist and sociocultural perspectives on mathematical development. Educational Researcher, 23(7), 13-20.

de Blij, H. (2009). The power of place: Geography, destiny, and globalization's rough landscape. New York, NY: Oxford University Press.

Ennaji, M. (2002). Language contact, Arabization policy and education in Morocco. In A. Rouchdy (Ed.), Language Contact and Language Conflict in Arabic (pp. 1-27). New York: Routledge.

Ennaji, M. (2005). Multilingualism, cultural identity, and education in Morocco. New York: Springer Science.

Fassi Fihri, A. (2003). Langue et écologie (Language and ecology), éditions Az-zaman, kitab al-jayb n 1 , Casablanca.

Fassi Fihri, A. (2013). Language policy in Arab Countries. In search for natural, fair, democratic and successful environment. Beyreuth: Dar Alkitab Aljadid Almuttahida.

Gharib, A. (1996). Language policy: Arabisation between high school and university. In The Arabisation of Education and the Environment (4th ed.). Morocco: The World of Education, p. 133-159.

Grandguillaume, G. (1983). Arabisation et politique linguistique au Maghreb. Paris: Maisonneuve.

Hammoud, M. (1982). Arabisation in Morocco: A case study in language and language policy attitudes. Ph.D. thesis. Rabat: University Mohamed V, Faculty of Letters.

Marley, D. (2004). Language attitudes in Morocco, following recent changes in language policy. Language Policy, 1, 25-46.

Oxford, R. (1997). Constuctivism: Shape-shifting substance and teacher education applications. Peabody Journal of Education, 72(1), 35-66.

Oxford, R., Park, S., \& Sumrall, M. (2008). Japanese by satellite: Effects of motivation, language learning styles and previous language learning experience on Japanese language achievement. Foreign Language Annals, 26(3), 359-371.

Pennycook, A. (2001). Critical applied linguistics: A critical introduction. Mahwah, NJ: Lawrence Erlbaum.

Phillips, D. (1995). The good, the bad and the ugly: The many faces of Constructivism. Educational Researcher, 24(7), 5-12.

Saidi, R. (2001). The teaching of modern standard Arabic to Moroccan pupils in elementary schools in the Netherlands: A study on proficiency, status and input. Unpublished doctoral dissertation, Universiteitsdrukkerij KUB, Tilburg.

Sapsford, R. (1999). Survey research. Los Angeles, CA: Sage Publications.

Taskakkori, A., \& Teddlie, C. (2003). Handbook of mixed methods in social and behavioral research. Thousand Oaks, CA: Sage.

World Bank Press Release. (2010). The world bank supports the implementation of Morocco's “Education Emergency Program 2009-2012." http://www.worldbank.org/en/news/press-release/ 2010/06/08/the-world-bank-supports-the-implementation-of-moroccos-education-emergencyprogram-2009-2012.

Zouhir, A. (2013). Language situation and conflict in Morocco. Conference paper presented at the 43rd Annual Conference on African Linguistics. Somerville, MA: Cascadilla Proceedings Project. 